\title{
Malabsorption of small doses of castor oil in patients without steatorrhoea
}

\author{
W. C. WATSON \\ From the University Department of Medicine, Royal Infirmary, Glasgow
}

EDITORIAL SYNOPSIS This paper presents a concept of malabsorption secondary to jejunal dysfunction in the presence of normal jejunal structure.

Steatorrhoea is an important but not invariable feature of the malabsorption syndrome. Occasionally the clinician will see a patient who has a megaloblastic anaemia, free acid in the gastric juice, a haematological response to folic acid, a flat jejunal biopsy and yet no steatorrhoea. Some of these patients seem to have pre-steatorrhoea in the sense that they develop steatorrhoea as their condition advances or in that their present capacity for fat absorption is barely adequate and might fail if tested by some functional overload.

It has been shown that small doses of castor oil are absorbed normally (Watson, Gordon, Karmen, and Jover, 1963), but that with increasing doses absorption decreases proportionately. It seemed possible that in the marginally normal bowel even a small dose of castor oil might be absorbed inadequately.

\section{METHODS}

${ }^{131}$ I-labelled castor oil, of medicinal purity, was prepared by the method of Rutenberg, Seligman, and Fine (1949). It was administered to patients from a weighed paper cup so that a known amount (approximately 4 g.) containing $20 \mu \mathrm{c}$. was given to each, and a known amount retained in the cup as a standard. It was given at 11 a.m. approximately three hours after a normal breakfast. This timing was important, for even the small dose caused diarrhoea on one occasion when given to a normal fasting subject.

A four-day faecal collection was made in a new 1-gallon paint can and the faecal fat and radioactivity were estimated as described previously (Watson et al., 1963).

Seventy-eight patients were studied and comprise three groups. Group 1, the normal or control group, consisted of 54 patients under investigation for peptic ulcer, chronic bronchitis, rheumatoid arthritis, rheumatic heart disease, and certain non-vascular neurological conditions. Group 2 consisted of 12 patients with various forms of malabsorption syndrome. The diagnosis for each patient is given in Table II. Group 3 emerged as the study progressed and is called the 'pre-steatorrhoea' group. None of the patients in it had steatorrhoea as determined by the chemical method of fatty acid titration, but all had definite malabsorption of the small dose of castor oil. The clinical and laboratory data for these patients are given in Table III.

\section{RESULTS}

The results of the faecal fat analyses and the ${ }^{131} \mathrm{I}$ castor oil balance studies for the three groups are summarized in Table $I$. The average daily faecal fatty acid excretion of $9.6 \mathrm{mEq}$. for the normal group of 54, with an upper limit of $21.3 \mathrm{mEq}$., corresponds closely to the figures of a larger series of 128 normals, of which the present group was a part (Watson and Dickson, 1964). The percentage recovery of the ${ }^{131}$ I-castor oil, namely, $2 \cdot 2 \pm 2 \cdot 4$ compares closely with $2.7 \pm 1.2$ for the ${ }^{131}$ I-triolein balance studies of Grossman and Jordan (1958), $3.0 \pm 1.9$ obtained by Pimparkar, Tulsky, Kalser, and Bockus (1960), and $2 \cdot 3 \pm 1 \cdot 3$ by Cox (1961).

In Cox's 67 normal cases without steatorrhoea, the range was 0.6 to $8.7 \%$. In the present group of

TABLE I

SUMMARIZED DATA FOR 78 PATIENTS STUDIED BY THE SMALL DOSE I $^{131}$-CASTOR OIL TEST

\begin{tabular}{|c|c|c|c|c|c|c|c|c|}
\hline \multirow{2}{*}{\multicolumn{2}{|c|}{ Group }} & \multirow[t]{2}{*}{ No. } & \multicolumn{3}{|c|}{ Faecal Fatty Acid (mEq./day) } & \multicolumn{3}{|c|}{ Percentage Recovery of ${ }^{131} I$} \\
\hline & & & Mean & S.D. & Range & Mean & S.D. & Range \\
\hline $\begin{array}{l}1 \\
2 \\
3\end{array}$ & $\begin{array}{l}\text { Normal } \\
\text { Malabsorption syndrome } \\
\text { Pre-steatorrhoea }\end{array}$ & $\begin{array}{l}54 \\
12 \\
12\end{array}$ & $\begin{array}{r}9 \cdot 6 \\
34 \cdot 9 \\
10 \cdot 9\end{array}$ & $\begin{array}{r}4 \cdot 6 \\
19 \cdot 0 \\
4 \cdot 3\end{array}$ & $\begin{array}{r}3 \cdot 0-21 \cdot 3 \\
17 \cdot 1-75 \cdot 0 \\
4 \cdot 1-16 \cdot 9\end{array}$ & $\begin{array}{r}2 \cdot 4 \\
6 \cdot 2 \\
27 \cdot 8\end{array}$ & $\begin{array}{r}2 \cdot 2 \\
4.9 \\
17 \cdot 5\end{array}$ & $\begin{array}{c}0 \cdot 2-9 \cdot 7 \\
0 \cdot 8-13 \cdot 8 \\
10 \cdot 6-77 \cdot 0\end{array}$ \\
\hline
\end{tabular}


54 normals without chemical steatorrhoea the range was 0.2 to $9.7 \%$. These comparisons show that in normal people without steatorrhoea the small dose castor oil test gives results similar to those of other series which have used radioactive triolein. The results also extend our previous experience in showing that in small doses, in normal subjects, castor oil is as efficiently absorbed as more normal dietary oils.

It was necessary to assess the small dose castor oil test in patients with proven steatorrhoea. The results for this group are given in detail in Table II, where the clinical diagnoses are also recorded. If a recovery of $5 \%$ of the dose is taken as the upper limit of normal, as did Cox, then only five of the 12 patients with chemical steatorrhoea had 'isotopic' steatorrhoea. This is in agreement with Cox's results for radioactive triolein. Although the range of his results for 33 patients was greater than for this smaller group of 12 , only 15 of his subjects had recoveries which were in excess of the $5 \%$ upper limit, and 18 had less than this. The results of the test for this group show, therefore, that the use of a small dose of ${ }^{131}$ I-castor oil reveals the same incidence of 'isotopic' steatorrhoea as the radioactive triolein test.
TABLE II

RESULTS OF SMALL DOSE ${ }^{131}$ I-CASTOR OIL TEST IN 12 PATIENTS WITH THE MALABSORPTION SYNDROME AND DEFINITE STEATORRHOEA, THAT IS, FAECAL FATTY ACID EXCRETION > $17 \mathrm{mEq}$./day (GROUP 2)

\begin{tabular}{|c|c|c|}
\hline Diagnosis & $\begin{array}{l}\text { Faecal Fatty } \\
\text { Acid } \\
(m E q . / \text { day })\end{array}$ & $\begin{array}{l}\text { Percentage } \\
\text { Recovery of } \\
\text { 131I }\end{array}$ \\
\hline Adult coeliac disease & $17 \cdot 1$ & $4 \cdot 2$ \\
\hline Adult coeliac disease & $20 \cdot 5$ & 6.8 \\
\hline Adult coeliac disease & $22 \cdot 0$ & $3 \cdot 6$ \\
\hline Adult coeliac disease & $59 \cdot 6$ & $10 \cdot 4$ \\
\hline Adult coeliac disease & $75 \cdot 0$ & $13 \cdot 6$ \\
\hline Chronic pancreatitis & $18 \cdot 3$ & $13 \cdot 8$ \\
\hline Carcinoma of pancreas & $56 \cdot 3$ & $11 \cdot 8$ \\
\hline Carcinoma of duodenum & $39 \cdot 5$ & $2 \cdot 8$ \\
\hline Mesenteric lymphosarcoma & $27 \cdot 4$ & 0.8 \\
\hline Postgastrectomy diarrhoea & $26 \cdot 2$ & $1 \cdot 6$ \\
\hline Mesenteric tuberculosis & $21 \cdot 3$ & 3.9 \\
\hline Addison's disease & $33 \cdot 5$ & $1 \cdot 3$ \\
\hline Mean \pm S.D. & $34 \cdot 9+19 \cdot 0$ & $6 \cdot 2 \pm 4 \cdot 9$ \\
\hline Range & $17 \cdot 1-75 \cdot 0$ & $0 \cdot 8-13 \cdot 8$ \\
\hline
\end{tabular}

Considering groups 1 and 2 together, it can be seen that whereas the test may err considerably in giving a $60 \%$ incidence of false negative results in patients with known steatorrhoea, it only gives $9 \%$ false positives if $5 \%$ is taken as the upper limit of normal, and none if $10 \%$ is taken. These figures

\section{TA BLE III}

CLINICAL AND LABORATORY DATA OF 12 PATIENTS FOUND ON SCREENING TO HAVE MALABSORPTION OF 131 I-LABELLED CASTOR OIL WITHOUT STEATORRHOEA

\begin{tabular}{|c|c|c|c|c|c|c|c|c|c|c|c|c|c|c|}
\hline & ient & $\operatorname{Sex}$ & $\begin{array}{l}\text { Age } \\
(y r .)\end{array}$ & $\begin{array}{l}\mathrm{Hb} \\
(\%)\end{array}$ & $\begin{array}{l}\text { M.C.H.C. } \\
(\%)\end{array}$ & Blood Film & $\begin{array}{l}\text { Serum } \\
\text { Iron } \\
(\mu g . \\
\%)\end{array}$ & $\begin{array}{l}\text { Satur- } \\
\text { ation } \\
(\%)\end{array}$ & $\begin{array}{l}\text { Xylose } \\
(\mathrm{g} . / 5 \mathrm{hr} .)\end{array}$ & $\begin{array}{l}\text { Faecal } \\
\text { Fat } \\
(m E q . ! \\
\text { day })\end{array}$ & $\begin{array}{l}{ }^{131} \text { I Rrecovery } \\
\text { (\% dose) }\end{array}$ & Radiology & $\begin{array}{l}\text { Jejunal } \\
\text { Biopsy }\end{array}$ & Comment \\
\hline 1 & S.M. & $\mathbf{F}$ & 60 & 52 & 22 & Iron deficiency & - & - & $3 \cdot 1$ & $\begin{array}{l}8 \cdot 4 \\
7 \cdot 2\end{array}$ & $\begin{array}{l}25 \cdot 3 \\
51 \cdot 3\end{array}$ & $\begin{array}{l}\text { Hiatus hernia } \\
\text { Diverticulitis }\end{array}$ & - & $\begin{array}{l}\text { Iron-deficiency } \\
\text { anaemia secondary to } \\
\text { alimentary blood loss }\end{array}$ \\
\hline 2 & H.F. & $\mathbf{F}$ & 66 & 45 & 23 & Iron deficiency & - & - & $5 \cdot 4$ & $14 \cdot 0$ & 21.9 & Negative & - & $\begin{array}{l}\text { Nutritional iron- } \\
\text { deficiency anaemia }\end{array}$ \\
\hline 3 & J.W. & F & 59 & 40 & 27 & Dimorphic anaemia & 40 & 12 & $1 \cdot 7$ & $4 \cdot 6$ & $77 \cdot 0$ & Negative & - & $\begin{array}{l}\text { Pernicious anaemia } \\
\text { and nutritional iron } \\
\text { deficiency }\end{array}$ \\
\hline 4 & F.M. & $\mathbf{F}$ & 70 & 65 & 31 & Iron deficiency & 7 & 2 & $3 \cdot 8^{1}$ & $14 \cdot 7$ & $36 \cdot 8$ & $\begin{array}{l}\text { Small bowel } \\
\text { diverticulitis, } \\
\text { dyspepsia }\end{array}$ & - & $\begin{array}{l}\text { Nutritional iron } \\
\text { deficiency and } \\
\text { alimentary bleeding }\end{array}$ \\
\hline 5 & J.S. & $\mathbf{F}$ & 40 & 51 & 28 & Iron deficiency & 38 & 9 & $5 \cdot 0$ & $4 \cdot 9$ & $12 \cdot 6$ & Negative & - & $\begin{array}{l}\text { Nutritional iron } \\
\text { deficiency and } \\
\text { multiple pregnancies } \\
\text { (16) }\end{array}$ \\
\hline 6 & M.F. & $\mathbf{F}$ & 64 & 45 & 26 & Iron deficiency & - & - & $7 \cdot 9$ & $11 \cdot 5$ & $25 \cdot 0$ & Negative & Normal & $\begin{array}{l}\text { Unexplained iron- } \\
\text { deficiency anaemia } \\
\text { and other vitamin } \\
\text { deficiencies }\end{array}$ \\
\hline 7 & I.R. & $\mathbf{F}$ & 57 & 43 & 24 & Iron deficiency & 35 & 5 & $4 \cdot 0$ & $16 \cdot 9$ & $18 \cdot 6$ & $\begin{array}{l}\text { Polya } \\
\text { gastrectomy }\end{array}$ & - & $\begin{array}{l}\text { Postgastrectomy iron } \\
\text { deficiency }\end{array}$ \\
\hline 8 & M.M. & $\mathbf{F}$ & 66 & 32 & 34 & Macrocytic & - & - & $4 \cdot 5$ & $10 \cdot 2$ & $22 \cdot 7$ & Negative & Normal & $\begin{array}{l}\text { Atypical megaloblastic } \\
\text { anaemia; allergic } \\
\text { vasculitis? auto- } \\
\text { immune disease }\end{array}$ \\
\hline 9 & J.J. & F & 23 & 43 & 20 & Iron deficiency & 20 & 3 & $9 \cdot 1$ & $10 \cdot 9$ & $10 \cdot 6$ & Negative & Normal & $\begin{array}{l}\text { Iron deficiency and } \\
\text { menorrhagia }\end{array}$ \\
\hline 0 & B.D. & $\mathbf{M}$ & 63 & 49 & 26 & Iron deficiency & 75 & 15 & $4 \cdot 2$ & $11 \cdot 9$ & $40 \cdot 1$ & Negative & Normal & $\begin{array}{l}\text { Iron deficiency and } \\
\text { haemorrhoids }\end{array}$ \\
\hline 1 & $\begin{array}{l}\text { A.H. } \\
\text { T.S. }\end{array}$ & $\begin{array}{l}\mathbf{M} \\
\mathbf{F}\end{array}$ & $\begin{array}{l}59 \\
65\end{array}$ & $\begin{array}{l}93 \\
84\end{array}$ & $\begin{array}{l}32 \\
33\end{array}$ & $\begin{array}{l}\text { Normal } \\
\text { Normal }\end{array}$ & - & - & 二 & $\begin{array}{r}11 \cdot 5 \\
4 \cdot 1\end{array}$ & $\begin{array}{l}11 \cdot 9 \\
23 \cdot 1\end{array}$ & 二 & 二 & $\begin{array}{l}\text { Myocardial infarction } \\
\text { Myocardial infarctio }\end{array}$ \\
\hline
\end{tabular}


mean that the small dose of castor oil test is not biased towards falsely high results, and comparison with other series shows that it gives representative normal and abnormal results when compared with the radioactive triolein test.

Table III summarizes the clinical and laboratory data for 12 patients who did not have chemical steatorrhoea but who, on the basis of castor oil recovery of more than $10 \%$, had isotopic steatorrhoea. Nos. 1 to 10 were under investigation primarily because of anaemia, and the average haemoglobin level for this group was $46.5 \%$. In nine of these iron deficiency of moderate to severe degree was present. Five of the 10 had a urinary xylose excretion of $4.2 \mathrm{~g}$. or less, although one of these had impaired renal function. Two of the 10 had megaloblastic anaemias. One (no. 6) had features of multiple vitamin deficiency. In four of the cases jejunal biopsy was performed and was normal.

Cases 11 and 12 were in the third week following a myocardial infarction. Neither was anaemic and neither complained of diarrhoea. Neither was on anticoagulants, so that the isotopic steatorrhoea cannot be attributed to phenindione, which occasionally causes diarrhoea and steatorrhoea.

\section{DISCUSSION}

The aspect of steatorrhoea which has been examined in this study is different from that of Parker and Ross (1960), who were concerned not with presteatorrhoea but with asymptomatic steatorrhoea. They followed up the suggestion of Cooke, Elkes, Frazer, Parkes, Peeney, Sammons, and Thomas (1946) that minor and potentially important anomalies of fat absorption were more common than was generally supposed. Using the serum carotene level as a screening test they investigated 230 convalescent patients who had no alimentary symptoms, and found that of 11 of these with low carotene levels, five had definite steatorrhoea, an incidence of $2.3 \%$.

The 12 patients described here are different. Ten were severely anaemic, nine being iron-deficient, and one had an unusual anaemia. Two were recovering from a myocardial infarction. None had steatorrhoea by chemical analysis. All, however, on the basis of the ${ }^{131} \mathrm{I}$-castor oil small dose test, had steatorrhoea of the isotopically labelled fat. Faecal samples contaminated by urine were discarded so that the phenomenon is not due to technical artefact.

There is however a difficulty in the use of ${ }^{131} \mathrm{I}$ labelled fats for fat balance studies, due to the instability of the label. The problem is not instability in vitro, for if the labelled oil is kept in the dark and used within three weeks there is a negligible release of free iodide. The problem is instability in vivo, where colonic bacteria may split off the label, which may then be absorbed from the colonic mucosa, giving falsely low results.

While this theoretical difficulty has to be acknowledged, it is unlikely to have affected materially the results of this study. In the initial paper on castor oil absorption in man (Watson et al., 1963) recovery data by two methods, isotopic balance and a special chemical balance technique, were compared, and with the exception of one case there was close agreement between the results. Again, the data of this paper showed that castor oil absorption was inversely related to the dose, and that small doses of 4 or $5 \mathrm{~g}$. were almost completely absorbed. The results for the 54 normal subjects in the present study are in keeping with these findings. Finally there is the remarkable homogeneity of the group separated from the controls by the small dose castor oil test. This group of 12 patients is either malabsorbing a small dose of castor oil, or, if the theoretical difficulties in the balance technique are practically significant, is manifesting a reduced degree of splitting of the radioactive label in vivo. There is clearly something different about this group in respect of its handling of the ${ }^{131} \mathrm{I}$-castor oil.

Anaemia, with the associated tissue hypoxia, interferes with cellular and enzymatic activity. Xylose absorption is impaired in pernicious anaemia (Helmer and Fouts, 1937; Bezman, Kinnear, and Zamcheck, 1959; Fowler and Cooke, 1960). Iron deficiency of a chronic and severe degree has long been known to be associated with gastric atrophy (Witts, 1930) and various degrees of chronic gastritis and gastric atrophy have been demonstrated in about $74 \%$ of patients with iron-deficiency anaemia (Davidson and Markson, 1955). It is unlikely that achlorhydria itself is the cause of the iron deficiency, since patients with uncomplicated pernicious anaemia are seldom iron deficient, and indeed the tissues of such patients are often replete with iron. It is equally unlikely that iron deficiency is the cause of the atrophy, since iron medication does not improve the gastric mucosa, judging by serial biopsy samples, and in fact deterioration may take place (Lees and Rosenthal, 1958). Recently Naiman, Oski, Diamond, Vawter, and Shwachman (1964) have described disordered small bowel function and structure in a large proportion of iron-deficient children. Their findings included imperfect absorption of xylose and fat and biopsy evidence of duodenitis and mucosal atrophy. Most of the abnormalities disappeared after oral iron treatment.

The mechanism for fat digestion and absorption is complex, and for castor oil it is normally less 
efficient than in the case of other dietary fats. Increasing complexity often means increasing vulnerability, and this may be why castor oil absorption deteriorates at a stage of failing function which is still adequate for other fats. It is also possible that it is some single step in the absorption pathway, peculiar to castor oil, which fails, and the test is detecting a precise defect in fat absorption of no importance to other fats. It is difficult to see what this might be. Some of the theoretical possibilities are discussed in detail elsewhere (Watson, 1964). It is, however, almost certain that the absorption difficulty is due to the special problems of molecular orientation which arise from the hydroxyl group on the straight chain which distinguishes ricinoleic from oleic acid.

The castor oil steatorrhoea found in two patients after a myocardial infarction is also of interest. Steatorrhoea is found in patients with mesenteric ischaemia, and this disorder most often occurs in association with generalized arterial disease. We have personal experience of two such cases and one of them had previously suffered a myocardial infarction. These implications are being followed up, and so far about $15 \%$ of patients in the third week after a 'myocardial infarction have been found to have steatorrhoea by the chemical method of estimation.

It must be stressed that the subjects of group 3 were not preselected. They were originally studied as part of a larger group of 66 patients screened by the small dose castor oil test and separated from it on the basis of a greater than $10 \%$ recovery of the dose. The fact that they fall into such a homogeneous clinical pattern is the more remarkable.

The concept of malabsorption secondary to jejunal dysfunction in the presence of normal jejunal structure is gaining ground. Lactase deficiency in adults may cause diarrhoea and lactase malabsorption although the jejunal mucosa is structurally normal (Kern, Struthers, and Attwood, 1963; McMichael, Webb, and Dawson, 1965). This may be digestive malabsorption, but the disaccharidase enzymes are located within the cells of the jejunal mucosa and their activity is likely to be intracellular. The steatorrhoea of hypoadrenalism is associated with a normal jejunal mucosa (McBrien, Jones, and Creamer, 1963) and once more the defect is possibly due to a lack of intracellular fatty acid activating enzymes (Watson and Murray, in press). In a recent paper on anaemia in relation to occult intestinal malabsorption, Whitehead, Carter, and Sharp (1965) report a patient with steatorrhoea $(11 \cdot 3 \mathrm{~g}$. faecal fat/day) and a normal jejunal biopsy. They do not, however, consider the alternative diagnoses. More information is needed before the concept of jejunal dysfunction in a structurally normal small bowel can be established, but this study and those mentioned above draw attention to the possibility.

\section{SUMMARY}

Small doses of ${ }^{131} \mathrm{I}$-castor oil were administered to 78 patients. In 54 subjects absorption was normal; in 12 subjects results typical of ${ }^{131}$ I-labelled fat balance studies were obtained; and in a clinically homogeneous group of subjects without steatorrhoea there was malabsorption of the small dose. A small dose of castor oil may be useful as a test for pre-steatorrhoea.

I wish to thank Professor E. M. McGirr for permission to study patients under his care. This work was supported in part by a U.S. Public Health Services returning fellow grant RF-35/C1, and in part by the Scottish Hospitals Endowment Research Trust grant 164.

\section{REFERENCES}

Bezman, A., Kinnear, D. G., and Zamcheck, N. (1959). D-xylose and potassium iodide absorption and serum carotene in pernicious anemia. J. Lab. clin. Med., 53, 226-232.

Cooke, W. T., Elkes, J. J., Frazer, A. C., Parkes, J., Peeney, A. L. P. Sammons, H. G., and Thomas, G. (1946). Anomalies of intestinal absorption of fat. I. The determination and significance of faecal fat. Quart. J. Med., 15, 141-155.

Cox, A. G. (1961). Assessment of the radiotriolein test in steatorrhoea. Brit. med. J., 2, 933-938.

Davidson, W. M. B., and Markson, J. L. (1955). The gastric mucosa in iron deficiency anaemia. Lancet, 2, 639-643.

Fowler, D., and Cooke, W. T. (1960). Diagnostic significance of the D-xylose excretion test. Gut, 1, 67-70.

Grossman, M. I., and Jordan, P. H., Jr. (1958). The radio-iodinated triolein test for steatorrhea. Gastroenterology, 34, 892-900.

Helmer, O. M., and Fouts, P. J. (1937). Gastro-intestinal studies. VII. The excretion of xylose in pernicious anemia. J. clin. Invest., 16, 343-349.

Kern, F., Jr., Struthers, J. E., Jr., and Attwood, W. L. (1963). Lactose intolerance as a cause of steatorrhea in an adult. Gastroenterology, 45, 477-487.

Lees, F., and Rosenthal, F. D. (1958). Gastric mucosal lesions before and after treatment in iron deficient anaemia. Quart. J. Med. 27, 19-26.

McBrien, D. J., Jones, R. V., and Creamer, B. (1963). Steatorrhoea in Addison's disease. Lancet, 1, 25-26.

McMichael, H. B., Webb, J., and Dawson, A. M. (1965). Lactase deficiency in adults. Ibid., 1, 717-720.

Naiman, J. L., Oski, F. A., Diamond, L. K., Vawter, G. F., and Shwachman, H. (1964). The gastrointestinal effects of iron deficiency anemia. Pediatrics, 33, 83-99.

Parker, J. G., and Ross, G. (1960). Incidence of asymptomatic steatorrhea in adults. Amer. J. dig. Dis., 5, 782-791.

Pimparkar, B., Tulsky, E. G., Kalser, M. H., and Bockus, H. L. (1960). Correlation of radioactive and chemical faecal fat in different malabsorption syndromes. Brit. med. J., 2, 894-900.

Rutenberg, A. M., Seligman, A. M., and Fine, J. (1949). Studies with radioactive iodized fat. I. Preparation of radioactive fat with observations on the absorption of fat following subcutaneous and intraperiotoneal injection in dogs. J. clin. Invest., 28 , 1105-1109.

Watson, W. C. (1964). Clinical and laboratory studies with castor oil. Ph.D. Thesis, University of Glasgow.

- and Dickson, C. (1964). Experience of a new procedure for faecal analysis. Gut, 5, 488-489.

_- Gordon, R. S. Jr., Karmen, A., and Jover, A. (1963). The absorption and excretion of castor oil in man. J. Pharm. Pharmacol., 15, 183-188.

- and Murray, E. (1966). Fat digestion and absorption in the adrenalectomized rat. J. Lipid Res. In the press.

Whitehead, R., Carter, R. L., and Sharp, A. A. (1965). Anaemia in occult intestinal malabsorption. J. clin. Path., 18, 110-113.

Witts, L. J. (1930). Simple achlorhydric anaemia. Guy's Hosp. Rep., 80, 253-296. 